\title{
A new species of Crocidosema Zeller (Lepidoptera, Tortricidae) from the Andes of northern Chile
}

\author{
HÉCTOR A. VARGAS ${ }^{1}$ \\ 1 Departamento de Recursos Ambientales, Facultad de Ciencias Agronómicas, Universidad de Tarapacá, Casilla 6-D, \\ Arica,Chile; havargas@uta.cl; lepvargas@gmail.com \\ http://zoobank.org/18830D74-3935-4277-9EA7-78C30A8FED48
}

Received 20 July 2019; accepted 25 August 2019; published: 27 September 2019

Subject Editor: David C. Lees

\begin{abstract}
Crocidosema nitsugai sp. nov. (Lepidoptera, Tortricidae, Olethreutinae, Eucosmini) is described and illustrated from the Andes of northern Chile based on adults obtained from larvae collected on leaves, flowers and unripe fruits and seeds of Lupinus oreophilus Phil. (Fabaceae). This represents the first record of insect herbivory on this Chilean endemic perennial herb. The genitalia morphology of $C$. nitsugai suggests a close evolutionary relationship with two congenerics from high elevation environments of the Ecuadorian and Peruvian Andes.
\end{abstract}

\section{Introduction}

Crocidosema Zeller, 1847 (Lepidoptera, Tortricidae, Olethreutinae, Eucosmini) is a mainly Neotropical genus with 69 described species, 45 of which have their type locality in South America (Gilligan et al. 2018). Many of the South American representatives were described in the last fifteen years based on the study of specimens collected relatively recently using light traps in different localities of Brazil, Colombia, Ecuador, Peru and Venezuela (Razowski and Wojtusiak 2006a, b, 2008a, b, 2009, 2010, 2011, 2013; Razowski and Becker 2014, 2017). Crocidosema insulana Aurivillius, 1922, is the only species of the genus native to Chile, originally described from Masatierra, Juan Fernandez Islands, and subsequently recorded from most of the mainland part of the country (Razowski and Pelz 2010). Crocidosema aporema Walsingham, 1914, an important pest of several legume crops described from Costa Rica and currently widespread in Central and South America (Gilligan and Epstein 2014), is also recorded from Chile in the agricultural literature (Artigas 1994).

The northernmost part of Chile has a considerable diversity of arid environments along a wide elevational gradient from the lowlands of the Atacama Desert to the highlands of the Andes (Luebert and Pliscoff 2006). Within this elevational gradient, records of native species of Tortricidae are mainly restricted to habitats below 1000 m elevation (Clarke 1987; Brito and Vargas 2018), with the exception of one species that reaches about $2000 \mathrm{~m}$ in the transverse valleys of the Atacama Desert (Vargas-Ortiz and Vargas 2018). However, the high elevation habitats of this region harbor a distinctive native flora (Gatica-Castro et al. 2015), some of whose species support populations of host-specific Lepidoptera (Vargas 2014; Ramírez-Fischer et al. 2016), suggesting that the current absence of records of Tortricidae in this area is likely a sampling artifact. In support of this suggestion, adults of this family were recently obtained from larvae collected on Lupinus oreophilus Phil. 
(Fabaceae), a perennial herb endemic to the elevational belt between 2700 and $4400 \mathrm{~m}$ in the Andes of northern Chile (Orrego et al. 2013). The Near Threatened status of populations of the shrub was recently proposed (Gatica-Castro et al. 2015). Subsequent examination of the morphology of the micromoths revealed that they represent a previously unknown species of Crocidosema, whose description is provided below.

\section{Material and methods}

The sampling was undertaken near Putre (18¹2'58'S; 69³3'38'W), Parinacota Province, at $3670 \mathrm{~m}$ elevation on the western slopes of the Andes of northern Chile. The site has a tropical xeric bioclimate with seasonal rains mainly concentrated between December and March (Luebert and Pliscoff 2006). This rainfall regime allows the development of a seasonal vegetation growth that reaches higher coverage shortly after the rains (Muñoz and Bonacic 2006). Larvae were collected on leaves, flowers and fruits of L. oreophilus in March 2019 following the summer rainfall. The collected larvae and the respective plant organs were placed in plastic vials with paper towel at the bottom and brought to the laboratory, where the vials were periodically cleaned and fresh leaves, flowers and fruits were provided until the larvae finished feeding and pupated. After pupation the vials were regularly observed until the emergence of adults, which were mounted. The abdomen of the adults was removed, cleared in hot $10 \% \mathrm{KOH}$ for a few minutes, stained with Eosin $\mathrm{Y}$ and Chlorazol black and slide-mounted with Euparal. Images were captured with Sony CyberShot DSC-HX200V and Micropublisher 3.3 RTV-QImaging digital cameras attached to a Leica M125 stereomicroscope and an Olympus BX51 optical microscope, respectively.

\section{Abbreviations of institutional collections}

MNNC Museo Nacional de Historia Natural de Santiago, Santiago, Chile

IDEA Colección Entomológica de la Universidad de Tarapacá, Arica, Chile

\section{Results}

Crocidosema nitsugai sp. nov.

http://zoobank.org/ABAD0B64-6794-4666-AE38-6471B431407A

Figs 1-5

Type material. HOLOTYPE, male, CHILE: Putre, Parinacota, Chile, emerged April 2019, H.A. Vargas coll., ex-larva Lupinus oreophilus, March 2019, genitalia slide HAV-1278 (MNNC).

Paratypes, CHILE. One male, two females, same data as holotype, genitalia slides HAV-1261, 1270, 1271 (MNNC); four males, one female, same data as holotype, genitalia slides HAV-1259, 1275, 1276, 1277, 1279 (IDEA).

Diagnosis. The genitalia of $C$. nitsugai are remarkably similar to those of $C$. marcapatae (Razowski \& Wojtusiak, 2010), described under Epinotia Hubner, [1825] from Cusco, Peru. However, the female genitalia of $C$. nitsugai have a parallel-sided antrum with the dorsal wall posteriorly 

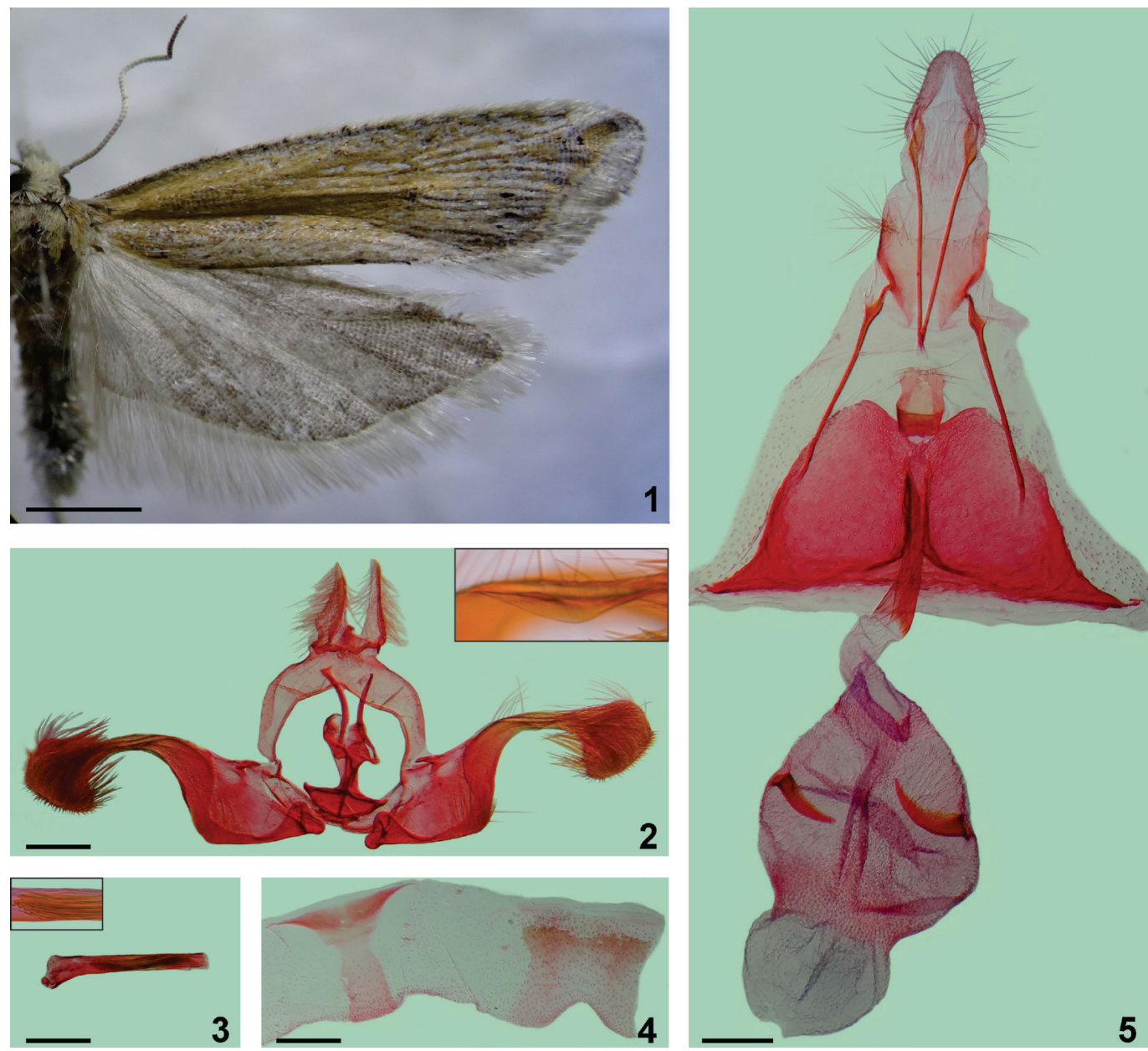

Figures 1-5. Adult stage of Crocidosema nitsugai sp. nov. 1. Holotype male in dorsal view. 2. Male genitalia in ventral view, phallus removed; upper right rectangle showing longitudinal carina on the neck of the right valva. 3. Phallus in lateral view; upper left rectangle showing base of cornuti. 4. Tergum (left) and sternum (right) of male abdominal segment VIII. 5. Female genitalia in ventral view. Scale bars: 2 mm (1), $0.3 \mathrm{~mm}(\mathbf{2 - 4}), 0.25 \mathrm{~mm}(\mathbf{5})$.

projected and the posterior margin of sternum VII widely notched at the middle. In contrast, those of $C$. marcapatae have a cup-shaped antrum without posterior projection of dorsal wall and posterior margin of sternum VII almost straight. In the male genitalia of $C$. nitsugai the neck of the valva is almost uniform in height throughout its length with a narrow longitudinal carina, and dorsal and ventral lobes of the cucullus are similar in size. In contrast, in C. marcapatae the neck of the valva is broadened on basal half and lacks carina, and the dorsal lobe of the cucullus is conspicuously smaller than the ventral lobe. The female genitalia of $C$. nitsugai also resemble those of C. pusula Razowski \& Becker, 2014, described from Carchi, Ecuador. However, the parallel-sided antrum, cingulum longer than the larger signum and two longitudinal stripes along the middle of sternum VII of $C$. nitsugai contrast with the cup-shaped antrum, cingulum slightly shorter than the smaller 
signum and absence of longitudinal stripes on the sternum VII of C. pusula. The male of C. pusula is unknown, impeding comparisons with $C$. nitsugai.

Description. Male. (Figs 1-5) Forewing length 8.5-9.5 mm.

Head. Vertex and frons mainly whitish gray with a few scattered grayish brown scales. Labial palpus mainly grayish brown with a few scattered whitish gray scales. Antenna whitish gray.

Thorax. Mainly yellowish brown dorsally with a few scattered dark gray scales, whitish gray latero-ventrally; patagium grayish brown. Foreleg with anterior face grayish brown, posterior face whitish gray. Midleg similar to foreleg in coloration, tibial spurs whitish gray. Hindleg whitish gray, including tibial spurs. Forewing mainly yellowish brown with abundant whitish gray and grayish brown scales intermixed outside the discal cell, a few scattered dark gray scales near external margin; fringe grayish brown. Hindwing mainly grayish brown, scattered whitish gray scales, fringe whitish gray.

Abdomen. Grayish brown. Tergum VIII (Fig. 4) somewhat T-shaped; anterior margin straight; lateral margin widely excavated on anterior half; posterior margin about $1 / 3$ the width of anterior margin. Sternum VIII somewhat square-shaped, posterior margin widely excavated in the middle.

Male genitalia (Figs 2, 3). Tegumen with anterior and posterior margins mainly parallel. Uncus cylindrical, slightly sclerotized, broadened basally, apex rounded, covered with hair-like setae. Socius slightly longer than uncus, narrow, tapering apically. Juxta semicircular, dorsal margin straight. Henion (sclerite between anellus and gnathos) narrow, elongated, well sclerotized, slightly longer than socius. Valvae symmetrical, wide incision on ventral margin; base of valva triangular; sacculus narrow; neck of valva almost uniform in height throughout its length, a narrow longitudinal carina on medial face; cucullus densely covered with hair-like scales, dorsal and ventral lobes similar in size. Phallus cylindrical, slightly longer than sacculus, slightly broadened basally; vesica with several spine-shaped cornuti.

Female. Similar to male in maculation and size.

Female genitalia (Fig. 5). Papillae analis narrow, elongated, slightly sclerotized, with hair-like setae. Posterior apophysis spine-shaped, slightly broadened basally, about twice length of papillae analis. Anterior apophysis similar to posterior apophysis in shape and length. Tergum VIII with U-shaped notch on anterior margin. Sternum VII with anterior margin straight; lateral margin widely excavated close anterior margin; posterior margin bilobed, widely notched in middle; two mainly parallel longitudinal stripes along the middle diverging close the anterior margin. Antrum parallel-sided, dorsal wall posteriorly projected. Ductus bursae slightly curved, membranous basally and apically; a well-developed cingulum with apex exceeding anterior margin of sternum VII. Corpus bursae membranous, pear-shaped, about 1.5 times length of ductus bursae; two slightly curved saw-like signa laterally.

Geographic distribution. Crocidosema nitsugai is known only from the type locality, in the surroundings of Putre, Parinacota Province, at 3670 m elevation on the Andes of northern Chile (Fig. 6).

Host plant. The only host plant currently known for $C$. nitsugai is the perennial herb Lupinus oreophilus Phil. (Figs 7-9), upon which the larvae feed on leaves, flowers and unripe fruits and seeds.

Etymology. The specific epithet is dedicated to the memory of the great Paraguayan guitarist and composer Agustín Pío Barrios, also known as Nitsuga Mangoré, as an acknowledgement to his amazing musical contribution. 

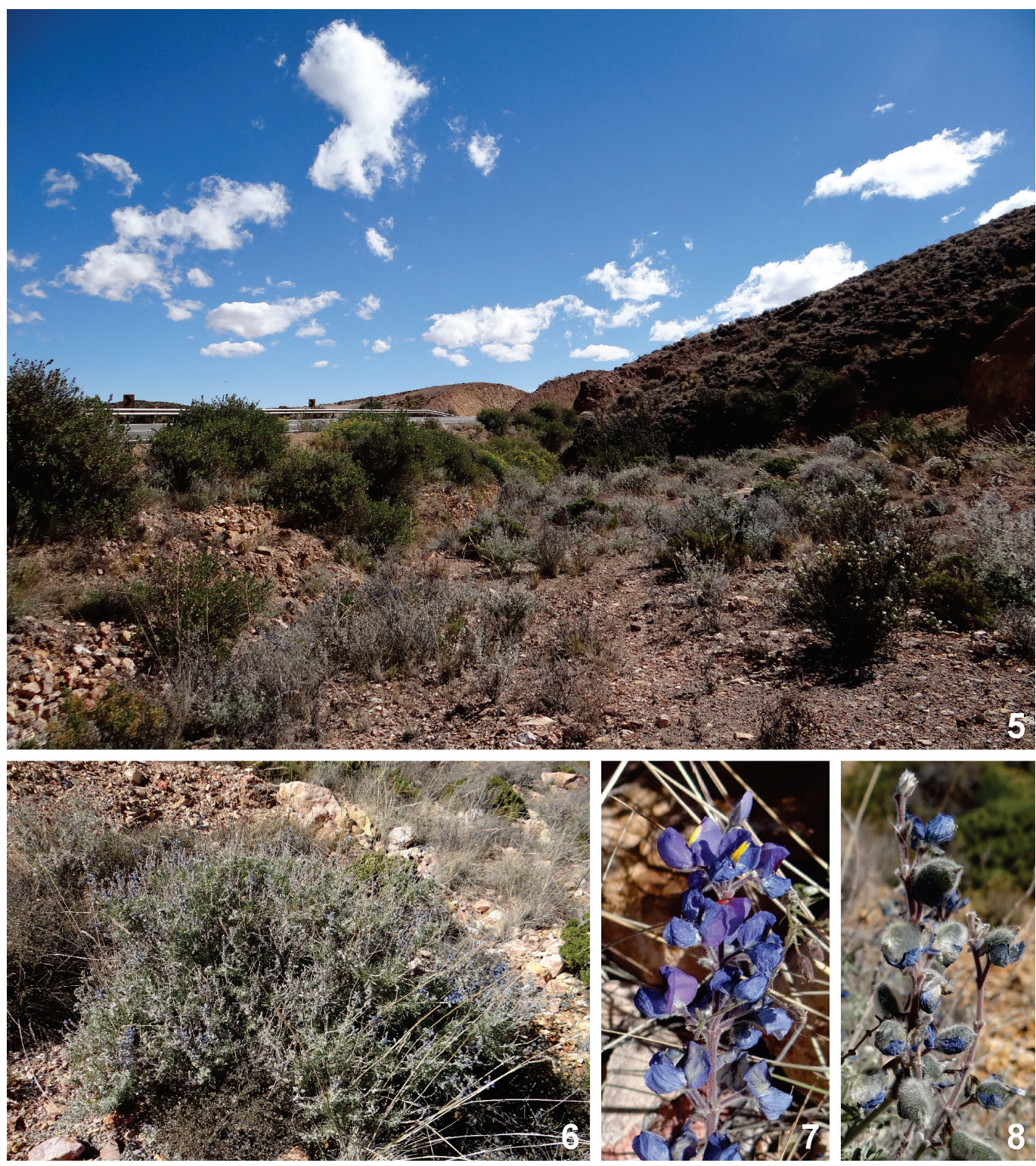

Figures 6-9. Habitat and host plant of Crocidosema nitsugai sp. nov. 6. Habitat of C. nitsugai in the type locality, near Putre, Parinacota Province, at 3670 m elevation on the Andes northern Chile. 7. The host plant Lupinus oreophilus. 8. Inflorescence of $L$. oreophilus. 9. Fruits of $L$. oreophilus.

\section{Discussion}

Although many species of Crocidosema have been described recently from the Neotropics, the discovery of $C$. nitsugai during a short field trip following the summer rainfall in the type locality highlights the need for additional sampling in different Neotropical environments to more accurately characterize the taxonomic diversity of this genus. Surveys of native plants appear to be 
especially valuable, because these provide the first insights on the host range of each newly found species (e.g. Brito and Vargas 2018). Host plants have been recorded for only nine species of Crocidosema, six of which feed on plants of only one family, whereas three feed on plants of more than one family. At one extreme is the widespread C. plebejana Zeller, 1847, whose larvae have been collected on representatives of nine families (Brown et al. 2008). Fabaceae has been recorded as host for four species of Crocidosema (Brown et al. 2008), among which only the Neotropical pest C. aporema feeds on Lupinus (Callohuari et al. 2018).

Crocidosema nitsugai represents the first record of insect herbivory on L. oreophilus. Previous studies indicated consumption of $L$. oreophilus by two herbivorous rodents in high elevation environments of the Andes of northern Chile (Cortés et al. 2002). The host plant range of C. nitsugai appears to be narrow, as it was absent in surveys undertaken on about ten plants of each of the additional native species of Fabaceae found in the study site: Adesmia verrucosa Meyen, A. spinosissima Vogel, Dalea pennellii (J.F. Macbr.) J.F. Macbr. var. chilensis Barneby and Senna birostris (Dombey ex Vogel) H.S. Irwin \& Barneby var. arequipensis (Meyen ex Vogel) H.S. Irwin \& Barneby. However, surveys for C. nitsugai should be expanded to additional Fabaceae of northern Chile outside the study site, where three other species of Lupinus have been recorded (Gatica-Castro et al. 2015). In addition, as Near Threatened status was recently proposed for L. oreophilus (Gatica-Castro et al. 2015), further studies are needed to understand better the effect of herbivory by larvae of $C$. nitsugai on populations of this plant.

The Andes uplift has been recognized as an important event in the diversification of several Neotropical animal groups, including Lepidoptera (Massardo et al. 2015; De-Silva et al. 2016). Unfortunately, despite a few recent additions (Vargas and Mundaca 2016; Vargas 2018), the taxonomy and natural history of the micromoths of the Andes of northern Chile have been little studied, impeding further evolutionary studies with these organisms. Indeed, C. nitsugai is the first species of Tortricidae described from these arid high elevation environments. Its genitalia are remarkably different of those of $C$. insulana, the only other representative of the genus native to Chile (Razowski and Pelz 2010), suggesting that they are only distantly related. The close morphological resemblance of the genitalia of $C$. nitsugai with those of other two highland species, C. marcapatae (Cusco, Peru, $3600 \mathrm{~m}$ ) and C. pusula (Carchi, Ecuador, $2200 \mathrm{~m}$ ), suggest that a group of closely related Crocidosema diversified along the still underexplored high elevation environments of the Andes, an evolutionary scenario that should be assessed in further studies.

\section{Acknowledgements}

I thank John W. Brown and David C. Lees for valuable suggestions on a previous version of the manuscript, Sebastián Espinoza-Donoso for editing the figures, Lafayette Eaton for checking the English and my brother Alberto for introducing me to the wonderful music of Nitsuga Mangoré.

\section{References}

Artigas JN (1994) Entomología Económica. Insectos de interés agrícola, forestal, médico y veterinario. Ediciones Universidad de Concepción, Concepción, Chile. 943 pp.

Brito R, Vargas HA (2018) A new leaf-tying Episimus Walsingham (Lepidoptera: Tortricidae) feeding on the vulnerable tree Haplorhus peruviana (Anacardiaceae) in the Atacama Desert of northern Chile. Studies on Neotropical Fauna and Environment 53: 113-119. https://doi.org/10.1080/01650521.2017.1413824 
Brown JW, Robinson G, Powell JA (2008) Food plant database of the leafrollers of the world (Lepidoptera: Tortricidae) (Version 1.0). http://www.tortricid.net/foodplants.asp [accessed 25 Jun 2019]

Callohuari YT, Vergara CE, Jiménez JE (2018) Insect pests associated with Andean lupin (Lupinus mutabilis Sweet) and their parasitoids in Peruvian central coast (Lima, La Molina). Peruvian Journal of Agronomy 2: 27-33. https://doi.org/10.21704/pja.v2i2.1199

Clarke JFG (1987) Two new Cryptophlebia Walsingham from Chile. (Lepidoptera: Tortricidae). Acta Entomológica Chilena 14: 7-12.

Cortés A, Rau JR, Miranda E, Jiménez JE (2002) Hábitos alimenticios de Lagidium viscacia y Abrocoma cinerea: roedores sintópicos en ambientes altoandinos del norte de Chile. Revista Chilena de Historia Natural 75: 583-593. https://doi.org/10.4067/S0716-078X2002000300009

De-Silva DL, Elias M, Willmott K, Mallet J, Day JJ (2016) Diversification of clearwing butterflies with the rise of the Andes. Journal of Biogeography 43: 44-58. https://doi.org/10.1111/jbi.12611

Gatica-Castro A, Marticorena A, Rojas G, Arancio G, Squeo FA (2015) Estado de conservación de la flora nativa de las regiones de Arica-Parinacota y de Tarapacá, Chile. Gayana Botánica 72: 305-339. https://doi. org/10.4067/S0717-66432015000200013

Gilligan TM, Baixeras J, Brown JW (2018) T@RTS: Online World Catalogue of the Tortricidae (Ver. 4.0). http://www.tortricid.net/catalogue.asp [accessed 28 May 2019]

Gilligan TM, Epstein ME (2014) TortAI, Tortricids of Agricultural Importance. http://idtools.org/id/leps/tortai/index.html [accessed 24 Jun 2019]

Luebert F, Pliscoff P (2006) Sinopsis bioclimática y vegetacional de Chile. Editorial Universitaria, Santiago. 316 pp.

Massardo D, Fornel R, Kronforst M, Gonçalves GL, Moreira GRP (2015) Diversification of the silverspot butterflies (Nymphalidae) in the Neotropics inferred from multi-locus DNA sequences. Molecular Phylogenetics and Evolution 82: 156-165. https://doi.org/10.1016/j.ympev.2014.09.018

Muñoz AE, Bonacic C (2006) Variación estacional de la flora y vegetación en la precordillera andina de la comuna de Putre (I Región de Tarapacá, Chile) durante el período 2002-2003. Gayana Botánica 63: 75-92. https://doi.org/10.4067/S0717-66432006000100003

Orrego F, Watson J, Flores AR, Rojas G (2013) Flores del Norte Grande. Jack Stern y CL, Museo Nacional de Historia Natural y SMC, Santiago. 165 pp.

Ramírez-Fischer FJ, Benyamini D, Vargas HA (2016) An endangered hemiparasitic shrub is the only host plant of the little-known Neotropical hairstreak Strymon flavaria (Lepidoptera: Lycaenidae) in the arid Andes. Journal of Insect Conservation 20: 923-928. https://doi.org/10.1007/s10841-016-9919-1

Razowski J, Becker VO (2014) Systematics and faunistics of Neotropical Eucosmini, 2: Epinotia Hübner, Catastega Clemens, and Crocidosema Zeller (Lepidoptera: Tortricidae). Polish Journal of Entomology 83: 23-59. https://doi.org/10.2478/pjen-2014-0003

Razowski J, Becker VO (2017) Systematics and faunistics of Neotropical Eucosmini, 3: Epinotia-group of genera (Lepidoptera: Tortricidae). Polish Journal of Entomology 86: 303-345. https://doi.org/10.1515/ pjen-2017-0018

Razowski J, Pelz V (2010) Tortricidae from Chile (Lepidoptera: Tortricidae). SHILAP Revista de Lepidopterología 38: 5-55.

Razowski J, Wojtusiak J (2006a) Tortricidae (Lepidoptera) in the valley of Río Gualaceo, East Cordillera in Ecuador, with descriptions of new taxa. Acta Zoologica Cracoviensia 49B: 17-53. https://doi. org/10.3409/000000006783995346

Razowski J, Wojtusiak J (2006b) Tortricidae from Venezuela (Lepidoptera: Tortricidae). SHILAP Revista de Lepidopterología 34: 35-79.

Razowski J, Wojtusiak J (2008a) Tortricidae from the Mountains of Ecuador. Part III: Western Cordillera (Insecta: Lepidoptera). Genus 19: 497-575. 
Razowski J, Wojtusiak J (2008b) Tortricidae (Lepidoptera) from the mountains of Ecuador. Part 1: Southern Highlands. Acta Zoologica Cracoviensia 51B: 7-41. https://doi.org/10.3409/azc.51b_1-2.7-41

Razowski J, Wojtusiak J (2009) Tortricidae (Lepidoptera) from the Mountains of Ecuador and remarks on their geographical distribution. Part IV: Eastern Cordillera. Acta Zoologica Cracoviensia 51B: 119-187. https://doi.org/10.3409/azc.52b_1-2.119-187

Razowski J, Wojtusiak J (2010) Tortricidae (Lepidoptera) from Peru. Acta Zoologica Cracoviensia 53B: 73159. https://doi.org/10.3409/azc.53b_1-2.73-159

Razowski J, Wojtusiak J (2011) Tortricidae (Lepidoptera) from Colombia. Acta Zoologica Cracoviensia 54B: 103-128. https://doi.org/10.3409/azc.54b_1-2.103-128

Razowski J, Wojtusiak J (2013) Accessions to the fauna of Neotropical Tortricidae (Lepidoptera). Acta Zoologica Cracoviensia 56: 9-40. https://doi.org/10.3409/azc.56_1.09

Vargas HA (2014) Lycaenid caterpillars (Lepidoptera, Lycaenidae) eating flowers of Dalea pennellii var. chilensis (Fabaceae) in the northern Chilean Andes. Revista Brasileira de Entomologia 58: 309-312. https://doi.org/10.1590/S0085-56262014000300015

Vargas HA (2018) A new species of Ypsolopha Latreille (Lepidoptera, Ypsolophidae) from the Andes of northern Chile. Nota Lepidopterologica 41: 199-205. https://doi.org/10.3897/nl.41.28570

Vargas HA, Mundaca EA (2016) First high-altitude record of Bucculatrix mirnae Vargas and Moreira (Lepidoptera, Bucculatricidae) on a newly documented host plant: the importance of host plant distribution for conservation on the western slopes of the Andes mountains of northern Chile. Revista Brasileira de Entomologia 60: 356-358. https://doi.org/10.1016/j.rbe.2016.06.007

Vargas-Ortiz M, Vargas HA (2018) A new species of Strepsicrates Meyrick (Lepidoptera: Tortricidae) from the Atacama Desert of northern Chile previously misidentified as S. smithiana Walsingham. Zootaxa 4370: 569-579. https://doi.org/10.11646/zootaxa.4370.5.8 